\title{
7
}

\section{Claudins and Germ Cell Tumors}

\author{
Ylermi Soini \\ Department of Pathology and Forensic Medicine, Institute of Clinical Medicine, \\ Pathology and Forensic Medicine, School of Medicine, University of Eastern Finland, \\ Cancer Center of Eastern Finland, Kuopio, \\ Finland
}

\section{Introduction}

Tight junctions are cellular structures present in epithelial, endothelial and mesothelial cells $(1,2,3)$. They are located at the apicolateral part of the cell membrane and regulate the paracellular permeability of cell layers which is called the gate function (4). They also have a fence function segregating the apical region of the cell membrane from the lateral parts preventing proteins of the apical area from mixing up with those of the lateral regions $(1,4)$. Tight junctions also take part in determination of cellular polarity $(1,4)$. They prevent pathogens from invading into the subepithelial tissues and thus can be considered to represent one part of the innate immune system (5).

In freeze fraction electron microscopy tight junctions form a beltlike branching structure around the cell which varies from $0.27 \mu \mathrm{m}$ to $0.37 \mu \mathrm{m}$ in thickness which depends on the cell type (6). Tight junctions are composed of membrane proteins and scaffolding proteins. The former include claudins, occludin, tricellulin and junctional adhesion molecules (7). Claudins, occluding and tricellulin have four transmembrane domains while junctional adhesion molecules have only one (7). Scaffolding proteins mediate interactions between tight junctions and the interior compartments of the cells. They include ZO-1 (Zona occludens-1), ZO-2, ZO-3, MAGI-1 (membrane-associated guanylate kinase with inverted orientation-1), cingulin and MUPP1 (multi-PDZ domain protein 1) (1,7).

\section{Claudins}

Claudins are tight junction proteins responsible for the regulation of paracellular permeability in cell layers. There are 27 claudins known and the diversity of claudins is the basis for differences in the solute and electrical permeability in different cell layers $(1,8)$ (Table 1). In kidney tubules different claudins are expressed in different areas of the nephron determining the solute and electrolytic permeability in different regions of the kidney tubule (9). A similar segmental distribution in claudin expression is observed in the gut (10). Claudins do not share structural resemblance to either occludin or tricellulin (11).

Claudins are key components of tight junctions $(1,4)$. They are 21-28kDa proteins containing an aminoterminal intracellular part, four transmembrane domains, two extracellular loops, an intracellular loop and an intracellular carboxyterminal end $(1,4,5,7)$. The carboxyterminal 


\begin{tabular}{|c|c|c|c|c|c|}
\hline Claudin & $\begin{array}{l}\text { Chromosomal } \\
\text { location }\end{array}$ & $\begin{array}{c}\text { Molecular } \\
\text { weight }(\mathrm{kDa})\end{array}$ & $\begin{array}{l}\text { Mutations/ } \\
\text { disease }\end{array}$ & $\begin{array}{c}\text { Splice } \\
\text { variants }\end{array}$ & Other aspects \\
\hline CLD1 & 3q28-29 & 22.7 & $\begin{array}{l}\text { Ictyosis, } \\
\text { Sclerosing } \\
\text { cholangitis }\end{array}$ & & $\begin{array}{l}\text { Entry cofactor for hepatitis C } \\
\text { virus, right-left patterning in } \\
\text { embryogenesis, knockdown } \\
\text { causes transdermal water loss }\end{array}$ \\
\hline CLD2 & Xq22.3-q23 & 24.5 & - & 5 & $\begin{array}{l}\text { Knockdown prevents bile } \\
\text { canalicular formation }\end{array}$ \\
\hline CLD3 & $7 q 11.23$ & 23.3 & & & Receptor for CPE \\
\hline CLD4 & 7q11.23 & 22.0 & & & Receptor for CPE \\
\hline CLD5 & $22 q 11.21$ & 23.1 & & & $\begin{array}{l}\text { Present mainly in } \\
\text { endothelium, heart } \\
\text { development in Xenopus, } \\
\text { knockdown causes } \\
\text { disturbances in BBB function }\end{array}$ \\
\hline CLD6 & $16 \mathrm{p} 13.3$ & 23.3 & & & $\begin{array}{l}\text { Entry cofactor for hepatitis C } \\
\text { virus }\end{array}$ \\
\hline CLD7 & 17 & 22.4 & & 3 & $\begin{array}{l}\text { Knockdown decreases Cloride } \\
\text { permeability }\end{array}$ \\
\hline CLD8 & 21.22 .11 & 24.8 & & & \\
\hline CLD9 & $16 \mathrm{p} 13.3$ & 22.8 & & & $\begin{array}{l}\text { Entry cofactor for hepatitis C } \\
\text { virus }\end{array}$ \\
\hline CLD10 & $13 q 31-34$ & $24.2-24.5$ & & 6 & \\
\hline CLD11 & 3q26.2-q26.3 & 21.9 & $\begin{array}{l}\text { Deafness, } \\
\text { Sertoli cell } \\
\text { dysfunction }\end{array}$ & & $\begin{array}{l}\text { Knockdown causes nerve } \\
\text { conduction disturbances, male } \\
\text { sterility, deafness }\end{array}$ \\
\hline CLD12 & $7 q 21$ & 27.1 & & 3 & $\begin{array}{l}\text { D vitamin induced Ca } \\
\text { abrorption from enterocytes }\end{array}$ \\
\hline CLD14 & $21 \mathrm{q} 22.3$ & 25.7 & $\begin{array}{l}\text { Sensoryneural } \\
\text { deafness }\end{array}$ & 5 & $\begin{array}{l}\text { Reduced mineral bone density, } \\
\text { kidney stones, } \\
\text { knockout causes deafness }\end{array}$ \\
\hline CLD15 & 7q11.22 & 24.3 & & 2 & $\begin{array}{l}\text { Megaintestine in knockout } \\
\text { mice }\end{array}$ \\
\hline CLD16 & $3 q 28$ & 33.8 & $\begin{array}{l}\text { Hypomagnese } \\
\text { mia type } 3\end{array}$ & & \\
\hline CLD17 & $21 q 22.11$ & 24.6 & & & Intronless gene \\
\hline CLD18 & $3 q 22.3$ & $27.7-27.9$ & & 2 & $\begin{array}{l}\text { Present in lung, } \\
\text { gastrointestinal tract }\end{array}$ \\
\hline CLD19 & $1 \mathrm{p} 34.2$ & $22.0-23.2$ & $\begin{array}{c}\text { Hypomagnese } \\
\text { mia with ocular } \\
\text { involvement }\end{array}$ & 2 & $\begin{array}{l}\text { Knockout affects nerve } \\
\text { conduction }\end{array}$ \\
\hline CLD20 & $6 \mathrm{q} 25$ & 23.5 & & & \\
\hline CLD21 & $4 q 35.1$ & 25.4 & & & \\
\hline CLD22 & $4 q 35.1$ & 25.5 & & & Intronless gene \\
\hline CLD23 & $8 \mathrm{p} 23.1$ & 31.9 & & & $\begin{array}{l}\text { Expressed in germinal center B } \\
\text { cells, stomach, placenta }\end{array}$ \\
\hline CLD24 & $4 q 35.1$ & 22.8 & & & \\
\hline CLD25 & $11 \mathrm{q} 23.2$ & & & & \\
\hline
\end{tabular}

Claudins 13, 26 and 27 are not found in humans

Table 1. Some characteristics of different claudins present in humans 
end contains the PDZ domains by which scaffolding proteins like ZO1 and ZO2 attach to claudins $(1,12)$. The larger of the extracellular loops (EL1) influences paracellular charge selectivity and contains the co-receptor site for Hepatitis C virus (HCV) $(1,12)$. The smaller loop (EL2) mediates attachment of the claudin molecule to the corresponding one of the neighbouring cell and also contains the oligomerisation site and receptor site for clostridium perfringens enterotoxin (CPE) $(1,12)$ (Figure 1).

The larger loop (EL-1) regulates paracellular electrical and solute permeability. The smaller loop (EL-2) mediates attachment between claudins of different cells. Four transmembrane domains separate the ends of the loops from the intracellular sequences of the molecules. The intracellular carboxyterminal end contains attachment sites for the PDZ domains of ZO1, ZO-2 and ZO-3 molecules. It also contains phosphorylation sites which influence the function of claudins.

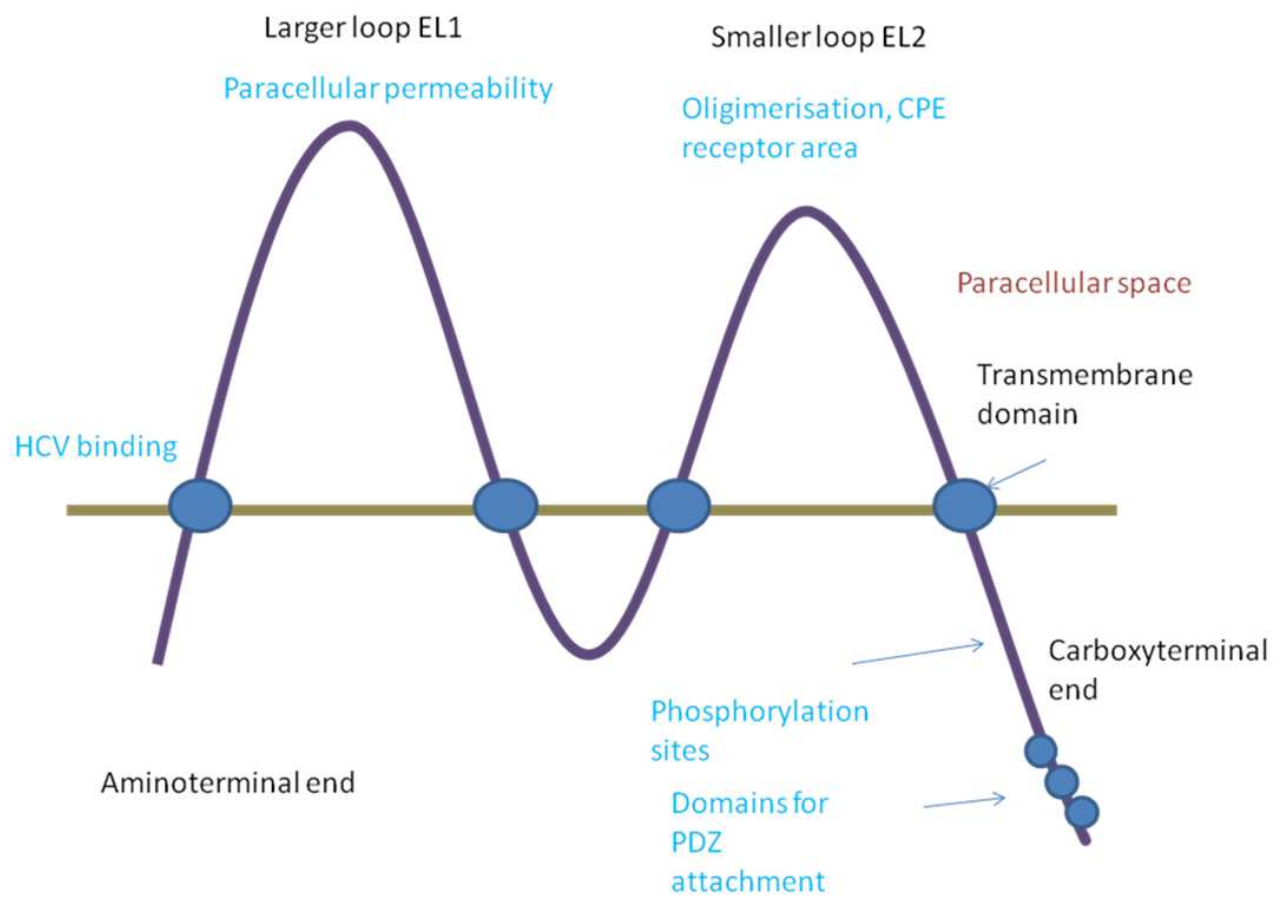

Fig. 1. A schematic presentation of the general molecular structure of claudins. Claudins form a structure formed by two extracellular loops (EL-1 and EL-2) in the cell membrane. 
Claudins may associate with each other as homodimers or heterodimers (1). Heterodimerisation occurs selectively between specific claudins, for example, Claudins 1 can heterodimerise with 4 but not with 2 (1). In addition to such vertical association between neigbouring cells, claudins also bind to one another laterally on cell membranes to form the tight junctional strand (1). Claudin 2 expression in tight junctions generally leads to a leakier barrier function (1).Generally, claudins 2, 7, 10, 15 and 16 increase paracellular cation permeability by forming pores in the tight junctions whereas claudins $4,5,8,11,14$ and 18 have an opposite function (1).

Claudins are widely expressed in epithelial cells but they are also found in endothelial and mesothelial cells, and in glial cells $(2,3,13,14)$. Several types of claudins are expressed in epithelial cells, but their distribution may vary according to the cell type and tissue site in question (2). Some claudins have a characteristic distribution. Claudin 5 is found in endothelial cells but it is also found in epithelium especially in neoplasia $(1,2)$. Claudin 11 is found in oligodendrocytes and in Sertoli cells but its expression has also been shown in endothelial cells of the corpus cavernosus $(15,16)$.

\subsection{Claudins in disease}

Claudin expression is modified in many diseases including both neoplastic and nonneoplastic conditions $(5,17)$. In cancers derived from epithelial cells claudin expression may be increased or decreased (17).The expression of claudins varies in tumors at different sites (7) and is different in head and neck (18), pancreatic (19), colonic $(20,21)$, ovarian (22), and breast cancers (23) as well as within the same site like in gastric cancer, where there is lower expression of claudins in diffuse carcinoma compared to the intestinal type (24). In breast cancer claudin 4 expression is increased and its expression is found in more aggressive types of tumors (25). Claudin 16 expression, on the other hand, is associated with a better prognosis (26). Moreover, claudin 7 is downregulated in many cancers, such as breast and colon carcinoma, where its diminished expression is also associated with a poor prognosis $(21,27)$.

In non-epithelial cancers, claudin expression has been found in malignant mesotheliomas, tumors derived from cells lining serosal cavities (3). The expression of claudins is, however, lower than that found in epithelial tumors and the difference in claudin expression can be used in the differential diagnosis between mesotheliomas and adenocarcinomas metastatic to the lung (3). Such findings have been substantiated in many reports indicating that claudin 3 and 4 might be especially useful in this respect $(3,28)$.

Claudins may also be useful in the differential diagnosis between soft tissue tumors and carcinomas, especially when such tumors are poorly differentiated and their origin is hard to substantiate based on morphology alone. Soft tissue tumors generally do not express claudins, exceptions are synovial sarcomas which also morphologically contain epithelial elements, and perineurinomas $(29,30)$. Furthermore, hemangiomas and angiosarcomas express claudin 5, by which expression they can be distinguished from other soft tissue tumors (2).

In non-neoplastic diseases claudin expression may be deranged in diseases where the permeability of cell layers is disturbed. Such conditions include intestinal and kidney diseases, vascular diseases and lung diseases with a diminished or lost cellular permeability 
leading to tissue edema. In various inflammations, claudin expression may be deranged. Examples of such are chronic colitis, like Crohn's disease or colitis ulcerosa where expression of claudins have been changed $(31,32)$. Many intestinal pathogens, such as aggressive strains of E coli, may lower the electrical and solute permeability of intestinal epithelia through displacement or downregulation of claudins and tight junctional scaffolding proteins leading to loss of fluid to the intestinal lumen $(33,34)$. Claudins may also serve as receptors for bacterial toxins and viruses. Claudin 1 serves as a coreceptor for hepatitis virus 1, and several viruses may modify tight junctional permeability by downregulation or displacement of claudins from the tight junction $(35,36,37,38)$. Also bacterial toxins may use claudins as receptors. The toxin secreted by clostridium perfringens uses claudin 3 and 4 as receptors to open up paracellular spaces between cells (39). This also leads to cellular destruction and clostridium perfringens enterotoxins has been used in experimental models as a chemical to destroy ovarian and prostate cancer cells which have a high expression of claudins 3 and 4 (39). Additionally, modified clostridium perfringens enterotoxin (CPE) can be used in treatment of cancer to enable penetration of cytostatic drugs to cancer tissues $(5,39)$.

In the kidney, claudins are differentially expressed along the tubular segments leading to a modulated anionic and solute permeability in different regions of the segments which is detrimental for the absorption functions of the kidney (9). Claudins 16 and 19, for instance, regulate $\mathrm{Mg}$ and $\mathrm{Cl}$ permeability of the kidney tubular cells and mutations in these claudins lead to disturbances of the permeability of these electrolytes (40). In lung diseases like ARDS, expression of claudin 4 is downregulated leading to increased permeability of the alveolar wall $(41,42)$. Counteracting claudin 4 downregulation could thus be one putative treatment for this often fatal lung disease.

\subsection{Claudins in gonadal structures}

In mRNA and array analysis indicate that claudins 1, 2, 3, 5, 7, 8, 10, 11, 12, and 23 are present in testicular tissue of rodents. Claudin 11 is found to be the highest (15). Such studies do not, however, indicate the location of claudin mRNA, and claudin 5 mRNA, for instance, may also partly be derived from endothelial cells.

In human testicular tissues claudin 1, 6 and 7 protein expression has been found in seminiferous tubules (43). In rete testis epithelium, claudins 1 and 7 are strongly expressed while claudin 4 is weak and claudins 3,5 and 6 are negative (43). Claudin 11 is present in Sertoli cells and takes part in formation of the blood testis barrier (44). In normal seminiferous epithelium claudin 11 is located at the basal compartment and the distribution is similar to ZO1 and ZO2 in this location (45). Claudin 1, 3 and 11 expression in Sertoli cells of mouse and rat testis appears to be regulated by androgens $(46,47,48)$. Also gonadotropins regulate the expression of tight junctional proteins such as claudin 11 and occludin (49).

Expression of claudins and other tight junction proteins have not been studied in ovaries to such an extent as in the testis. Trace amounts of claudin 1, 2, 4, 5, 7, 10, 11, 12 have been detected in normal ovarian tissues (17). Ovarian surface epithelial cells express claudin 1 , ZO1 and occludin (50). Ovarian HOSE (human ovarian surface epithelial) cells do not express claudins 3 or 4 (51). On the other hand, in array based analysis, ovarian serous 
cancer cells displayed a strong mRNA expression of claudins 3,4 and 7 compared to non-neoplastic cells (52). Claudin 3 and 4 expression appears to be nonexistent in surface ovarian cells but is increased in ovarian cysts (53).

\section{Germ cell tumors}

Germ cell tumors represent a tumor group derived from primordial germ cells of the body (54). They develop in testicular and ovarial tissues but are also found at extragonadal sites such as the mediastinum, and hypothalamic or suprasellar regions. Up to $95 \%$ of testicular tumors are of germ cell derivation while in ovaries they make up only of 3-5\% of the tumor cases (55). Germ cell tumors of the testis develop from intratubular germ cell neoplasia (ITGCN) (except for spermatocytic seminoma and infantile germ cell tumors) and their development is linked to maturation arrest.The corresponding ovarian counterpart for ITGCN is gonadoblastoma (56).

Germ cell tumors can be divided in pure and mixed form (54). Pure germ cell tumors are composed of only one tumor component while mixed tumors consist of two or more (54). Testicular mixed germ cell tumors represent 30 to $50 \%$ of the tumors while in the ovaries they represent about $20 \%$. The commonest pure germ cell tumor is seminoma/dysgerminoma representing $50 \%$ and $40 \%$ of testicular and ovarian germ cell tumors, respectively. Embryonal carcinoma is composed of undifferentiated cells with an epithelial appearance and it is more common in testis than in ovaries $(54,57)$. Yolk sac tumor, on the other hand, is relatively more common in the ovaries (57). There are many histologic patterns, such as microcystic, papillary, macrocystic, hepatoid, solid and glandular-alveolar patterns, often mixed with each other (54). The tumor recapitulates the structures of yolk sac, the allantoin membrane and extraembryonic mesenchyme (54). It contains hyaline globules and Schiller-Duval bodies (57). Choriocarcinoma is rare both in ovaries and testis (54). It is composed of neoplastic cytotrophoblastic and syncytiotrophoblastic cells intermixed with hemorrhagic and necrotic background (54). Examples of benign germ cell tumors are teratomas which display a mixture of mature endodermal, mesodermal or ectodermal components (54). In some teratomas one component may predominate. Such is the case in dermoid cysts which contain a predominant component of cutaneous tissue leading to a cystic tumor containing keratin and hair structures (58). In immature teratomas or teratomas with somite type malignancies one or more components of the cell layers is malignant (54).

Immunohistochemical markers useful in the diagnosis of germ cell tumors include AFP and HCG which are positive in yolk sac tumor and choriocarcinoma, respectively $(54,59)$. PLAP is invariably present in both but also in seminoma and embryonal carcinoma $(54,59)$. They both express OCT3/4 which is not present in yolk sac tumor or choriocarcinoma $(54,59)$. Embryonal carcinoma expresses SOX2 and CD30 which are not present in seminoma which, on the other hand, expresses SOX $17(54,59)$.

\section{Claudins in germ cell tumors}

Germ cell tumors are neoplasms which are derived and may express several cell types of the ectoderm, endoderm or mesoderm. There are also many times a mixture of different cell 
components in these tumors (54). Of benign germ cell tumors a good example is teratoma which contains full developed components of epithelial, mesodermal and/or neural elements $(54,58)$. Claudin expression in these tumors is analogous to the expression found in tissues of the comparable non-neoplastic tissues in human body (43). Thus expression of claudins 1, 2, 3, 4, 5 and 7 is usually amply found but expression is different in squamous or glandular epithelia (43). Squamous epithelium expresses strongly claudin 1 and 4 but claudin 3 is weakly or negatively expressed (43). On the other hand, glandular epithelia express claudin 3 strongly in teratomas (43). Claudin 7 is strongly expressed in both of these epithelia, but claudin 5 and 6 are negative (43). The different expression of claudins 3 and 4 is also reflected in malignant tumors derived from squamous or glandular epithelia. Adenocarcinomas of the oesophagus show a significantly higher expression of claudin 3 than squamous cell carcinomas (60). A similar situation is found for between lung squamous cell and adenocarcinomas (61). Mesenchymal tissues are generally negative for claudins with the exception of claudin 5 which is expressed in endothelial cells (2). Blood vessels may also show expression of some other claudins, like claudins 2 and 3 (2). Tissues found in teratomas are, however, many and strong conclusions cannot be drawn based on materials consisting only of some cases.

Teratocarcinomas express variable levels of claudins 1, 2, 3, 4 and 7 in carcinomatous elements but some cases display also positivity for claudins 5 and 6 (43). Claudin 5 which is mainly an endothelial marker and partly responsible for the function of blood brain or blood testis barrier $(15,62)$ is overexpressed in several carcinomas, like ovarian or lung carcinomas $(61,63,64)$. The expression appears to be present in poorly differentiated tumors in serous ovarian carcinomas and is associated with a worse survival (64). Such expression may reflect a more primitive nature of the epithelial tumor cells but may also be an expression of vascular mimicry in tumors reflecting the capacity of neoplastic epithelial cells to attain endothelial features, a phenomenon described in melanomas, sarcomas and carcinomas $(65,66)$. Whether expression of claudin 5 in teratocarcinomas influences behavior of these tumors is, however, unknown.

In tumor biology, derivation of malignant tumors has been suggested, on one hand, to clonal evolution of malignant cells, on the other hand, tumors have been suggested to develop through stem cells $(67,68)$. In clonal evolution there is a constant development of varied population of malignant cells and the most apt ones having the best survival capabilities to survive and make up the bulk of the tumors and develop metastases $(67,68)$. According to the stem cell theory, tumors contain a population of stem cells which are present in specific locations (niche) in tumors (68). These cells which produce cancer tissue through dysregulation of asymmetric division are the basic invasive and metastasizing elements of the tumor and the rest are a more differentiated bulk which have not a significant impact on the spread and survival of the cells (68). Primitive pluripotent stem cells do not usually express antigens. Organ specific stem cells already committed to a specific differentiation can, however, be characterized by specific antigens (69). Such antigens present in breast carcinomas are CD44 and CD25, for instance (69). Of claudins, claudin 6 has been suggested to be an early epithelial stem cell marker (70). In line with this claudin 6 was present in a proportion of epithelial elements of teratocarcinomas, and in embryonal carcinomas but also in yolk sac or choriocarcinomatous elements suggesting that such claudin 6 positive stem cell may also differentiate towards extraembryonic cells (43). 
Generally, however, claudins are parts of an element which is a sign of differentiation in epithelia, and their presence on the cell membrane of epithelia speaks for the presence of functioning tight junctions $(1,2)$. Thus, a feature expected for a stem cells could be a lack of claudin expression. Indeed, in breast carcinoma, a claudin low population of breast carcinomas, having a low expression of claudins 3, 4 and 7 has been characterized to represent a tumor with similar features to the triple negative breast tumors and having a significant overlap with them (71). Even though there is a diminished expression of claudin 3 and 4 in embryonal carcinoma and claudin 3 in teratocarcinoma, both tumors express strongly claudin 7 and generally express claudins $1-7$. The concept of stem cells cannot thus be addressed through diminished or absent claudin expression in germ cell tumors.

Embryonal carcinomas are primitive tumors committed to the epithelial lineage. In line with this they express claudins 1-7 (43). There is only one study which has investigated claudin expression in these tumors, but work has also been carried out in embryonal carcinoma cell lines. In the studies of Sawada et al, the F9 embryonal carcinoma cell line expressed the studied claudins 6 and 7 and this expression was induced by hepatocyte nuclear factor alpha (72). It also induced the formation of tight junctions and a polarised morphology of these cells and retarded cellular proliferation by upregulation p21 (72). Differentiation of embryonal cells to embryoid bodies increase the mRNA of several claudins, such as claudins 2, 6 and 7 and also occludin (73).

Seminomas are primitive germ cell tumors which have a specific morphology consisting of nests of large round cells which are usually surrounded by an inflammatory infiltrate consisting of small lymphocytes (54). Seminomas express strongly claudin 7 but some cases express also claudin 5 (43). The specific expression of these claudins in seminomas with lack of claudins 3, 4 and 1 clearly distinguishes these tumors from other germ cell tumors (43). Seminomas also display a strong expression of twist suggesting that it might be one factor contributing to the lack of expression of these claudins (43). Twist expression is associated with a poor prognosis in some tumors, such as breast carcinoma, but generally the expression of twist is low in carcinomas (74). It, however, is supposed to contribute to epitheliomesenchymal transition (EMT) in organ specific tumors which is also in line with the association with this function (74). A high expression of twist in seminomas probably signifies an inherent character of these tumor cells to express this transcription factor and it probably has another function in such a non-epithelial neoplasm. There are, however, no clinical studies assessing the prognostic value of twist or claudins in seminoma or other germ cell tumors.

Choriocarcinomas are aggressive tumors differentiating towards trophoblastic cells (54). Areas of choriocarcinoma are many times present in mixed germ cell tumors and pure choriocarcinomas are rare (54). They consist of large, neoplastic trophoblastic cells with areas of strong hemorrhage (54). Choriocarcinoma cells have an especially strong expression of claudin 4 (43). Claudin 4 is commonly present in epithelial neoplasms and in several tissues and it is considered to have a sealing function on paracellular membranes (1). In lung diseases, for instance, claudin 4 is downregulated in acute respiratory distress syndrome and lung inflammations contributing to the development of lung edema $(41,42)$. Claudin 4 also serves as a receptor for clostridium perfringens enterotoxin, and chemically modified enterotoxins have been used in cancer treatment to facilitate penetration of chemotherapeutics to claudin 4 positive tumors (39). The significance of the strong 
expression of claudin 4 in choriocarcinoma cells is obscure but suggests that its expression may be important for the function of trophoblastic cells.

Intratubular germ cell neoplasia is the precursor lesion of germ cell neoplasms of the testis (54). In studies on claudin 11 expression in these lesions, claudin 11 expression was increased but the increased did not take place in the neoplastic germ cells but in Sertoli cells where claudin 11 was displaced from the membrane (45). The relative protein expression of claudins 1-7 in testicular germ cell neoplasia and testicular tissue is presented in Table 2 (43).

\begin{tabular}{|c|c|c|c|c|c|c|}
\hline $\begin{array}{l}\text { Germ cell tumor } \\
\text { component }\end{array}$ & claudin 1 & claudin 3 & claudin 4 & claudin 5 & claudin 6 & claudin 7 \\
\hline seminoma & - & - & - & ++ & - & ++ \\
\hline embryonal carcinoma & ++ & + & + & ++ & ++ & +++ \\
\hline teratocarcinoma & +++ & + & +++ & ++ & ++ & +++ \\
\hline teratoma & +++ & ++ & +++ & ++ & ++ & +++ \\
\hline chorioncarcinoma & - & - & ++ & + & + & + \\
\hline \multicolumn{7}{|l|}{ Testicular tissue } \\
\hline seminiferous tubules & + & - & - & - & + & + \\
\hline Rete testis epithelium & +++ & - & + & - & - & +++ \\
\hline
\end{tabular}

-=negative; $+=$ weak,$++=$ moderate, $+++=$ strong expression

Table 2. Summary of the average protein expression of claudins 1, 3, 4, 5, 6 and 7 in germ cell tumors and testicular tissues

\section{Claudins in diagnosis and treatment of germ cell tumors}

Seminomas differ from other germ cell tumors by their expression of claudin 5 and 7 and lack of other claudins (43). Choriocarcinoma, on the other hand, expresses claudin 4 strongly (43). However, germ cell tumors have a specific histopathologic character and many times it is easy to distinguish seminoma or chorioncarcinoma from other germ cell tumors. In lymph node metastases, analysis of claudins might be of some help. Seminomas in lymphatic tissues in the mediastinum, for instance, may resemble the syncytial variant of nodular sclerosis Hodgkin's disease which do not express claudins at all (2). Germ cell tumors, however, have already established markers and claudins may hardly will be of any additional help in their diagnosis (54).

Claudins 3 and 4 have been found to function as receptors for clostridium perfringens enterotoxin (CPE) (39). In prostate and ovarian cancer cell lines expressing claudins 3 and 4 clostridium perfringens enterotoxin is able to destroy such cells $(75,76)$. Claudins 3 and 4 are, however, expressed in many non-neoplastic cells so CPE cannot be used in treatment of cancer without side effects even though the cytotoxicity appears to be lower in nonneoplastic cells (76). Chemically modified CPE has, however, been used to open up tight junctions in cancer treatment experiments to allow a better penetrance of chemotherapeutic drugs to reach cancer cells (77). Such treatments strategy might also be possible in intratubular germ cell neoplasia when the tumor cells are still enveloped by the blood testis barrier. The main claudin responsible for the tight junctional permeability in the blood testis barrier is claudin 11, although claudins 3 and 5 also play some role (15). Additionally, CPE treatment based on cytotoxicity might be theoretically possible in those cases of germ cell neoplasia expressing claudins 3 and 4, like chorioncarcinoma or embryonal carcinoma (43). 


\subsection{Claudins in Sertoli cells}

The blood testis barrier is formed by tight junctions between adjacent Sertoli cells (15). Claudin 11 is obligatory for the function and formation of tight junctional barrier in the testis (15). In claudin 11 knockout mice, Sertoli cells are detached from the seminiferous tubules and attain fibroblastoid features (78). In androgen receptor depleted mice the development of tight junctions of Sertoli cells is deranged with aberrations in the expression of several genes including occludin, claudin 11 and $3(79,80)$. Additionally, also claudin 5 mRNA has been detected in seminiferous epithelial cells and its expression is increased in mice at the time of blood testis barrier development (15). The expression of claudin 5 was dependent on ets variant gene 5 (ETV5) and germ cells (15). Interestingly, claudin 5 was not affected by ETV 5 in vascular structures of the testis (15). The loss of claudin 5 expression in Sertoli cells resulted in an elevated solute permeability as detected by biotin tracer leakage (15).

TGFbeta3 inhibits the expression of claudin 11, occludin and ZO1 by a MAP 38 kinase dependent mechanism in Sertoli cells (81). FSH and TNF alpha inhibits claudin 11 expression in Sertoli cell culture (82). Testosterone increases claudin $11 \mathrm{mRNA}$ expression in a dose dependent manner (47). The influence of antiandrogenic flutamide is complex (47). Fetally administered flutamide in mice resulted in prepubertal decrease of claudin 11 in Sertoli cells but the inhibition in adult testes was dose dependent, lower doses resulting in decreased expression (47). When given orally to 13 weeks' old rats, flutamide induced a decrease in the mRNA expression of occludin but did not affect claudin 1 or 11 mRNA (83). Thus androgens and gonadotropins may theoretically influence the penetrance of the blood testis barrier by modifying claudin 11 expression but such treatment strategy may lead to intolerable side effects perhaps through breakage of self tolerance and development of autoimmune diseases or reactions induced by exposure of self antigens normally hidden by the blood testis barrier.

\section{References}

[1] Krause G, Winkler L, Mueller SL, Haseloff RF, Piontek J, Blasig IE: Structure and function of claudins. Biochim Biophys Acta. 2008, 1778: 631-45

[2] Soini Y. Expression of claudins 1, 2, 3, 4, 5 and 7 in various types of tumours. Histopathology 2005;46:551-60.

[3] Soini Y, Kinnula V, Kahlos K, Pääkkö P: Claudins in differential diagnosis between mesothelioma and metastatic adenocarcinoma of the pleura. J Clin Pathol. 2006, 59: 250-4.

[4] Sawada N, Murata M, Kikuchi K, Osanai M, Tobioka H, Kojima T, Chiba H: Tightjunctions and human diseases. Med Electron Microsc. 2003, 36: 147-56.

[5] Soini Y. Claudins in lung diseases. Respir Res. 2011 May 27;12:70.

[6] Godfrey RW: Human airway epithelial tight junctions. Microsc Res Tech. 1997, 38: 488-99.

[7] Matter K, Balda MS. Epithelial tight junctions, gene expression and nucleo-junctional interplay. J Cell Sci. 2007, 120: 1505-11.

[8] Mineta K, Yamamoto Y, Yamazaki Y, Tanaka H, Tada Y, Saito K, Tamura A, Igarashi M, Endo T, Takeuchi K, Tsukita S. Predicted expansion of the claudin multigene family. FEBS Lett. 2011, 585:606-12. 
[9] Kirk A, Campbell S, Bass P, Mason J, Collins J. Differential expression of claudin tight junction proteins in the human cortical nephron. Nephrol Dial Transplant. 2010;25:2107-19.

[10] Holmes JL, Van Itallie CM, Rasmussen JE, Anderson JM. Claudin profiling in the mouse during postnatal intestinal development and along the gastrointestinal tract reveals complex expression patterns. Gene Expr Patterns. 2006;6:581-8.

[11] Hartsock A, Nelson WJ. Adherens and tight junctions: structure, function and connections to the actin cytoskeleton. Biochim Biophys Acta. 2008;1778:660-9.

[12] Lal-Nag M, Morin PJ: The claudins. Genome Biol. 2009, 10: 235.

[13] Mack AF, Wolburg H. Growing axons in fish optic nerve are accompanied by astrocytes interconnected by tight junctions. Brain Res. 2006;1103:25-31.

[14] Tiwari-Woodruff SK, Buznikov AG, Vu TQ, Micevych PE, Chen K, Kornblum HI, Bronstein JM. OSP/claudin-11 forms a complex with a novel member of the tetraspanin super family and beta1 integrin and regulates proliferation and migration of oligodendrocytes. J Cell Biol. 2001;153:295-305.

[15] Morrow CM, Mruk D, Cheng CY, Hess RA. Claudin and occludin expression and function in the seminiferous epithelium. Philos Trans R Soc Lond B Biol Sci. 2010;365:1679-96.

[16] Wessells H, Sullivan CJ, Tsubota Y, Engel KL, Kim B, Olson NE, Thorner D, Chitaley K. Transcriptional profiling of human cavernosal endothelial cells reveals distinctive cell adhesion phenotype and role for claudin 11 in vascular barrier function. Physiol Genomics. 2009;39:100-8.

[17] Hewitt KJ, Agarwal R, Morin PJ. The claudin gene family: expression in normal and neoplastic tissues. BMC Cancer. 2006;6:186.

[18] Al Moustafa AE, aoui-Jamali MA, Batist G, Hernandez-Perez M, Serruya C, Alpert L, Black MJ, Sladek R, Foulkes WD. Identification of genes associated with head and neck carcinogenesis by cDNA microarray comparison between matched primary normal epithelial and squamous carcinoma cells. Oncogene 2002;21:2634-2640.

[19] Tsukahara M, Nagai H, Kamiakito T, Kawata H, Takayashiki N, Saito K, Tanaka A. Distinct expression patterns of claudin-1 and claudin-4 in intraductal papillarymucinous tumors of the pancreas. Pathol Int 2005;55:63-69.

[20] Kinugasa T, Huo Q, Higashi D, Shibaguchi H, Kuroki M, Tanaka T, Futami K, Yamashita Y, Hachimine K, Maekawa S, Nabeshima K, Iwasaki H, Kuroki M. Selective up-regulation of claudin-1 and claudin-2 in colorectal cancer. Anticancer Res 2007;27:3729-3734.

[21] Oshima T, Kunisaki C, Yoshihara K, Yamada R, Yamamoto N, Sato T, Makino H, Yamagishi S, Nagano Y, Fujii S, Shiozawa M, Akaike M, Wada N, Rino Y, Masuda M, Tanaka K, Imada T. Reduced expression of the claudin-7 gene correlates with venous invasion and liver metastasis in colorectal cancer. Oncol Rep 2008;19:953959. 
[22] Agarwal R, D'Souza T, Morin PJ. Claudin-3 and claudin-4 expression in ovarian epithelial cells enhances invasion and is associated with increased matrix metalloproteinase-2 activity. Cancer Res 2005;65:7378-7385.

[23] Sauer T, Pedersen MK, Ebeltoft K, Naess O. Reduced expression of Claudin-7 in fine needle aspirates from breast carcinomas correlate with grading and metastatic disease. Cytopathology 2005;16:193-198.

[24] Soini Y, Tommola S, Helin H, Martikainen P. Claudins 1, 3, 4 and 5 in gastric carcinoma, loss of claudin expression associates with the diffuse subtype. Virchows Arch 2006;448:52-58.

[25] Lanigan F, McKiernan E, Brennan DJ, Hegarty S, Millikan RC, McBryan J, Jirstrom K, Landberg G, Martin F, Duffy MJ, Gallagher WM. Increased claudin-4 expression is associated with poor prognosis and high tumour grade in breast cancer. Int J Cancer. 2009;124:2088-97.

[26] Martin TA, Harrison GM, Watkins G, Jiang WG. Claudin-16 reduces the aggressive behavior of human breast cancer cells. J Cell Biochem. 2008;105:41-52.

[27] Sauer T, Pedersen MK, Ebeltoft K, Naess O. Reduced expression of Claudin-7 in fine needle aspirates from breast carcinomas correlate with grading and metastatic disease. Cytopathology. 2005;16:193-8.

[28] Facchetti F, Gentili F, Lonardi S, Bercich L, Santin A. Claudin-4 in mesothelioma diagnosis. Histopathology. 2007, 51: 261-3.

[29] Billings SD, Walsh SV, Fisher C, Nusrat A, Weiss SW, Folpe AL. Aberrant expression of tight junction-related proteins ZO-1, claudin-1 and occludin in synovial sarcoma: an immunohistochemical study with ultrastructural correlation. Mod Pathol. 2004;17:141-9.

[30] Folpe AL, Billings SD, McKenney JK, Walsh SV, Nusrat A, Weiss SW. Expression of claudin-1, a recently described tight junction-associated protein, distinguishes soft tissue perineurioma from potential mimics. Am J Surg Pathol. 2002;26:1620-6.

[31] Zeissig S, Bürgel N, Günzel D, Richter J, Mankertz J, Wahnschaffe U, Kroesen AJ, Zeitz M, Fromm M, Schulzke JD. Changes in expression and distribution of claudin 2, 5 and 8 lead to discontinuous tight junctions and barrier dysfunction in active Crohn's disease. Gut. 2007;56:61-72.

[32] Oshima T, Miwa H, Joh T. Changes in the expression of claudins in active ulcerative colitis. J Gastroenterol Hepatol. 2008;23:S146-50.

[33] Hering NA, Richter JF, Krug SM, Günzel D, Fromm A, Bohn E, Rosenthal R, Bücker R, Fromm M, Troeger H, Schulzke JD: Yersinia enterocolitica induces epithelial barrier dysfunction through regional tight junction changes in colonic HT-29/B6 cell monolayers. Lab Invest. 2011, 91: 310-324

[34] Strauman MC, Harper JM, Harrington SM, Boll EJ, Nataro JP: Enteroaggregative Escherichia coli disrupts epithelial cell tight junctions. Infect Immun. 2010, 78: 495864. 
[35] Evans MJ, von Hahn T, Tscherne DM, Syder AJ, Panis M, Wölk B, Hatziioannou T, McKeating JA, Bieniasz PD, Rice CM: Claudin-1 is a hepatitis C virus co-receptor required for a late step in entry. Nature. 2007, 446: 801-5.

[36] Yeo NK, Jang YJ: Rhinovirus infection-induced alteration of tight junction and adherens junction components in human nasal epithelial cells. Laryngoscope. 2010, 120: 346-52.

[37] Nazli A, Chan O, Dobson-Belaire WN, Ouellet M, Tremblay MJ, Gray-Owen SD, Arsenault AL, Kaushic C: Exposure to HIV-1 directly impairs mucosal epithelial barrier integrity allowing microbial translocation. PLoS Pathog. 2010, 6: e1000852

[38] Nava P, López S, Arias CF, Islas S, González-Mariscal L: The rotavirus surface protein VP8 modulates the gate and fence function of tight junctions in epithelial cells. J Cell Sci. 2004, 117: 5509-19.

[39] Van Itallie CM, Betts L, Smedley JG 3rd, McClane BA, Anderson JM: Structure of the claudin-binding domain of Clostridium perfringens enterotoxin. J Biol Chem. 2008, 283: 268-74.

[40] Hou J, Renigunta A, Gomes AS, Hou M, Paul DL, Waldegger S, Goodenough DA. Claudin-16 and claudin-19 interaction is required for their assembly into tight junctions and for renal reabsorption of magnesium. Proc Natl Acad Sci U S A. 2009;106:15350-5.

[41] Wray C, Mao Y, Pan J, Chandrasena A, Piasta F, Frank JA: Claudin-4 augments alveolar epithelial barrier function and is induced in acute lung injury. Am J Physiol Lung Cell Mol Physiol. 2009, 297: L219-27.

[42] Xia XM, Wang FY, Wang ZK, Wan HJ, Xu WA, Lu H: Emodin enhances alveolar epithelial barrier function in rats with experimental acute pancreatitis. World J Gastroenterol. 2010, 16: 2994-3001.

[43] Väre P, Soini Y. Twist is inversely associated with claudins in germ cell tumors of the testis. APMIS. 2010;118(9):640-7

[44] Bronstein JM, Chen K, Tiwari-Woodruff S, Kornblum HI. Developmental expression of OSP/claudin-11. J Neurosci Res. 2000;60:284-90.

[45] Fink C, Weigel R, Fink L, Wilhelm J, Kliesch S, Zeiler M, Bergmann M, Brehm R. Claudin-11 is over-expressed and dislocated from the blood-testis barrier in Sertoli cells associated with testicular intraepithelial neoplasia in men. Histochem Cell Biol. 2009;131:755-64.

[46] Gye MC. Expression of claudin-1 in mouse testis. Arch Androl. 2003;49:271-9..

[47] Florin A, Maire M, Bozec A, Hellani A, Chater S, Bars R, Chuzel F, Benahmed M. Androgens and postmeiotic germ cells regulate claudin-11 expression in rat Sertoli cells. Endocrinology. 2005;146:1532-40.

[48] Meng J, Holdcraft RW, Shima JE, Griswold MD, Braun RE. Androgens regulate the permeability of the blood-testis barrier. Proc Natl Acad Sci U S A. 2005;102:16696700.

[49] McCabe MJ, Tarulli GA, Meachem SJ, Robertson DM, Smooker PM, Stanton PG. Gonadotropins regulate rat testicular tight junctions in vivo. Endocrinology. 2010;151:2911-22. 
[50] Zhu Y, Maric J, Nilsson M, Brännström M, Janson PO, Sundfeldt K. Formation and barrier function of tight junctions in human ovarian surface epithelium. Biol Reprod. 2004;71:53-9.

[51] Agarwal R, D'Souza T, Morin PJ. Claudin-3 and claudin-4 expression in ovarian epithelial cells enhances invasion and is associated with increased matrix metalloproteinase-2 activity. Cancer Res. 2005;65:7378-85.

[52] Santin AD, Zhan F, Bellone S, Palmieri M, Cane S, Bignotti E, Anfossi S, Gokden M, Dunn D, Roman JJ, O'Brien TJ, Tian E, Cannon MJ, Shaughnessy J Jr, Pecorelli S. Gene expression profiles in primary ovarian serous papillary tumors and normal ovarian epithelium: identification of candidate molecular markers for ovarian cancer diagnosis and therapy. Int J Cancer. 2004;112:14-25.

[53] Zhu Y, Brännström M, Janson PO, Sundfeldt K. Differences in expression patterns of the tight junction proteins,claudin 1, 3, 4 and 5, in human ovarian surface epithelium as compared to epithelia in inclusion cysts and epithelial ovarian tumours. Int J Cancer. 2006;118:1884-91.

[54] Eble J, Sauter G, Epstein JI, Sesterhenn IA. Tumours of the Urinary system and Male Genital Organs, WHO Classification of Tumours. Lyon, France, 2004.

[55] Huyghe E, Matsuda T, Thonneau P. Increasing incidence of testicular cancer worldwide: a review. J Urol. 2003;170:5-11.

[56] Mancilla EE, Poggi H, Repetto G, Rumié H, García H, Ugarte F, Hidalgo S, Jara A, Muzzo S, Panteón E, Torrealba I, Foradori A, Cattani A. Y chromosome sequences in Turner's syndrome: association with virilization and gonadoblastoma. J Pediatr Endocrinol Metab. 2003;16:1157-63.

[57] Roth LM, Talerman A. Recent advances in the pathology and classification of ovarian germ cell tumors. Int J Gynecol Pathol. 2006;25:305-20.

[58] Tavassoli FA, Devilee P: Tumours of the breast and Female genital Organs. World Health Organization Classification of Tumours. IARC press, Lyon, France, 2003.

[59] Looijenga LH. Human testicular (non)seminomatous germ cell tumours: the clinical implications of recent pathobiological insights. J Pathol. 2009;218:146-62.

[60] Takala H, Saarnio J, Wiik H, Soini Y. Claudins 1, 3, 4, 5 and 7 in esophageal cancer: loss of claudin 3 and 4 expression is associated with metastatic behavior. APMIS. 2007;115:838-47.

[61] Merikallio H, Kaarteenaho R, Pääkkö P, Lehtonen S, Hirvikoski P, Mäkitaro R, Harju T, Soini $\mathrm{Y}$. Impact of smoking on the expression of claudins in lung carcinoma. Eur J Cancer. 2011;47:620-30.

[62] Nitta T, Hata M, Gotoh S, Seo Y, Sasaki H, Hashimoto N, Furuse M, Tsukita S.Sizeselective loosening of the blood-brain barrier in claudin-5-deficient mice. J Cell Biol. 2003;161:653-60.

[63] Soini Y, Talvensaari-Mattila A. Expression of claudins 1, 4, 5, and 7 in ovarian tumors of diverse types. Int J Gynecol Pathol. 2006;25:330-5. 
[64] Turunen M, Talvensaari-Mattila A, Soini Y, Santala M. Claudin-5 overexpression correlates with aggressive behavior in serous ovarian adenocarcinoma. Anticancer Res. 2009;29:5185-9.

[65] Hendrix MJ, Seftor EA, Hess AR, Seftor RE. Vasculogenic mimicry and tumour-cell plasticity: lessons from melanoma. Nat Rev Cancer. 2003;3:411-21.

[66] Folberg R, Maniotis AJ. Vasculogenic mimicry. APMIS. 2004;112:508-25.

[67] Barrett JC. Mechanisms of multistep carcinogenesis and carcinogen risk assessment. Environ Health Perspect. 1993;100:9-20.

[68] Sell S. On the stem cell origin of cancer. Am J Pathol. 2010;176:2584-494.

[69] Fábián A, Barok M, Vereb G, Szöllosi J. Die hard: are cancer stem cells the Bruce Willises of tumor biology? Cytometry A. 2009;75(1):67-74.

[70] Turksen K, Troy TC. Claudin-6: a novel tight junction molecule is developmentally regulated in mouse embryonic epithelium. Dev Dyn. 2001;222:292-300.

[71] Prat A, Parker JS, Karginova O, Fan C, Livasy C, Herschkowitz JI, He X, Perou CM. Phenotypic and molecular characterization of the claudin-low intrinsic subtype of breast cancer. Breast Cancer Res. 2010;12:R68

[72] Chiba H, Gotoh T, Kojima T, Satohisa S, Kikuchi K, Osanai M, Sawada N. Hepatocyte nuclear factor (HNF)-4alpha triggers formation of functional tight junctions and establishment of polarized epithelial morphology in F9 embryonal carcinoma cells. Exp Cell Res. 2003;286:288-97.

[73] Guillemot L, Hammar E, Kaister C, Ritz J, Caille D, Jond L, Bauer C, Meda P, Citi S. Disruption of the cingulin gene does not prevent tight junction formation but alters gene expression. J Cell Sci. 2004;117:5245-56.

[74] Soini Y, Tuhkanen H, Sironen R, Virtanen I, Kataja V, Auvinen P, Mannermaa A, Kosma VM. Transcription factors zeb1, twist and snai1 in breast carcinoma. BMC Cancer. 2011;11:73.

[75] Yuan X, Lin X, Manorek G, Kanatani I, Cheung LH, Rosenblum MG, Howell SB. Recombinant $\mathrm{CPE}$ fused to tumor necrosis factor targets human ovarian cancer cells expressing the claudin-3 and claudin-4 receptors. Mol Cancer Ther. 2009;8:1906-15.

[76] Maeda T, Murata M, Chiba H, Takasawa A, Tanaka S, Kojima T, Masumori N, Tsukamoto T, Sawada N. Claudin-4-targeted therapy using Clostridium perfringens enterotoxin for prostate cancer. Prostate. 2011[Epub ahead of print]

[77] Kondoh M, Takahashi A, Fujii M, Yagi K, Watanabe Y. A novel strategy for a drug delivery system using a claudin modulator. Biol Pharm Bull. 2006;29:1783-9.

[78] Mazaud-Guittot S, Meugnier E, Pesenti S, Wu X, Vidal H, Gow A, Le MagueresseBattistoni B. Claudin 11 deficiency in mice results in loss of the Sertoli cell epithelial phenotype in the testis. Biol Reprod. 2010;82:202-13.

[79] Wang RS, Yeh S, Chen LM, Lin HY, Zhang C, Ni J, Wu CC, di Sant'Agnese PA, deMesyBentley KL, Tzeng CR, Chang C. Androgen receptor in sertoli cell is essential for germ cell nursery and junctional complex formation in mouse testes. Endocrinology. 2006;147:5624-33. 
[80] Willems A, Batlouni SR, Esnal A, Swinnen JV, Saunders PT, Sharpe RM, França LR, De Gendt K, Verhoeven G. Selective ablation of the androgen receptor in mouse sertoli cells affects sertoli cell maturation, barrier formation and cytoskeletal development. PLoS One. 2010;5:e14168.

[81] Lui WY, Lee WM, Cheng CY. Transforming growth factor-beta3 perturbs the interSertoli tight junction permeability barrier in vitro possibly mediated via its effects on occludin, zonula occludens-1, and claudin-11. Endocrinology. 200;142:1865-77.

[82] Hellani A, Ji J, Mauduit C, Deschildre C, Tabone E, Benahmed M. Developmental and hormonal regulation of the expression of oligodendrocyte-specific protein/claudin 11 in mouse testis. Endocrinology. 2000;141:3012-9.

[83] Gye MC, Ohsako S. Effects of flutamide in the rat testis on the expression of occludin, an integral member of the tight junctions. Toxicol Lett. 2003;143:217-22. 


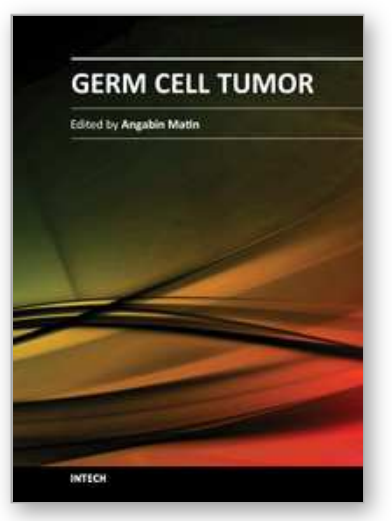

\author{
Germ Cell Tumor \\ Edited by Dr. Angabin Matin
}

ISBN 978-953-51-0456-8

Hard cover, 150 pages

Publisher InTech

Published online 30, March, 2012

Published in print edition March, 2012

The book aims to provide an overview of current knowledge regarding germ cell tumors. It deals with the clinical presentations, treatment modalities, the biology and genetics of germ cell tumors in children and adults. Most chapters are focused on testicular germ cell tumors whose incidence has been increasing in young males. Included are reviews on the pathogenesis, risk factors, diagnosis and treatment regimens applied to precursor, pre-invasive lesions as well as to seminomatous and non-seminomatous germ cell tumors of the testes. In addition, a review is included on the diagnosis and current management options for intracranial germ cell tumors in children. Authors have also contributed articles on the genetics and epigenetics of germ cell tumor development in humans and in the mouse model system. This book will be of interest to scientists, physicians and lay readers wishing to review recent developments in the field of germ cell cancers.

\title{
How to reference
}

In order to correctly reference this scholarly work, feel free to copy and paste the following:

Ylermi Soini (2012). Claudins and Germ Cell Tumors, Germ Cell Tumor, Dr. Angabin Matin (Ed.), ISBN: 978953-51-0456-8, InTech, Available from: http://www.intechopen.com/books/germ-cell-tumor/claudins-and-germcell-tumors

\section{INTECH}

open science | open minds

\section{InTech Europe}

University Campus STeP Ri Slavka Krautzeka 83/A 51000 Rijeka, Croatia Phone: +385 (51) 770447 Fax: +385 (51) 686166 www.intechopen.com

\author{
InTech China \\ Unit 405, Office Block, Hotel Equatorial Shanghai \\ No.65, Yan An Road (West), Shanghai, 200040, China \\ 中国上海市延安西路65号上海国际贵都大饭店办公楼405单元 \\ Phone: +86-21-62489820 \\ Fax: +86-21-62489821
}


(C) 2012 The Author(s). Licensee IntechOpen. This is an open access article distributed under the terms of the Creative Commons Attribution 3.0 License, which permits unrestricted use, distribution, and reproduction in any medium, provided the original work is properly cited. 